\title{
AKTYWNOŚĆ SZKÓŁ WYŻSZYCH W POLSCE NA RZECZ ROZWOJU SPOLECZNOŚCI LOKALNYCH - DYSKUSJA WOKÓŁ POJĘCIA TRZECIEJ MISJI UCZELNI
}

\begin{abstract}
Streszczenie
Artykuł dotyczy koncepcji tzw. trzeciej misji szkół wyższych, która obok kształcenia i prowadzenia badań naukowych staje się coraz ważniejszym wymiarem działalności akademickiej. Zasadniczym celem artykułu jest próba włączenia się w dyskusję dotyczącą zakresu pojęciowego trzeciej misji oraz jej znaczenia w działalności szkół wyższych dzięki krytycznej analizie literatury oraz prezentacji wyników badań własnych. Uzyskane wyniki wskazuja, że rektorzy szkół wyższych podzielaja zdanie autorki, która uważa, że trzecia misja oznacza wszystkie aktywności szkół wyższych dedykowane społecznościom lokalnym i regionalnym w obszarach: kształcenia, prowadzenia i udostępniania rezultatów badań naukowych, jak również wynikające z posiadania przez uczelnie określonych zasobów finansowych i rzeczowych. Ponadto, należy zauważyć, że aktywność uczelni w tym obszarze jest wyraźnie wyodrębniona w misjach i strategiach uczelni.
\end{abstract}

Słowa kluczowe: rozwój regionalny, szkoła wyższa, trzecia misja, zarządzanie szkołą wyższą

\section{ACTIVITY OF HIGHER EDUCATION INSTITUTIONS IN POLAND FOR DEVELOPMENT OF LOCAL COMMUNITIES: DEBATE ON THIRD MISSION OF HIGHER EDUCATION INSTITUTIONS}

\begin{abstract}
Summary
The paper discusses the concept of the third mission of higher education institutions (HEIs), which, besides education and scientific research, is becoming an increasingly important dimension of academic activity. The main aim of the paper is to contribute to the debate concerning the conceptual range of the third mission and its significance for HEIs ' activities through a critical study of the literature and a presentation of the author's own research. The results indicate that rectors share the author's standpoint that the third mission covers all the HEIs`activities targeting local and regional communities in the fields of education, conducting and providing access to scientific research, as well as the activities resulting from HEIs' financial and material resources. Apart from that, it is worth noticing that the third mission activities are explicitly outlined in the mission statements and strategies of HEIs.
\end{abstract}

Key words: regional development, higher education institution, third mission, management of higher education institutions

${ }_{1}^{1}$ Dr Agnieszka Piotrowska-Piątek - Urząd Statystyczny w Kielcach, Politechnika Świętokrzyska, Wydział Zarządzania i Modelowania Komputerowego; e-mail: a.piotrowska-piatek@stat.gov.pl. 


\section{Wstęp. Rola szkół wyższych w rozwoju regionów}

Niebywały wzrost znaczenia wiedzy w działalności współczesnych organizacji, procesy globalizacji, tendencje demograficzne, a w konsekwencji określone wymogi rynku pracy są katalizatorami zmian, jakie zachodzą w procesach zarządzania szkołami wyższymi w Polsce. Strategie zarządcze realizowane przez władze uczelni są również zdeterminowane założonym stopniem wypełniania ról, jakie są właściwe szkołom wyższym. Role te są zróżnicowane. $Z$ jednej strony można mówić o rolach przynależnych jedynie szkołom wyższym, które stanowia o istocie takich organizacji - jest to połączenie: procesu kształcenia, prowadzenia badań naukowych i upowszechniania ich rezultatów oraz działań na rzecz społeczności lokalnych i regionalnych. Natomiast druga grupa ról wynika $\mathrm{z}$ faktu, że uczelnie są określonymi, w rozumieniu rzeczowym, organizacjami. Uczelnia jest dysponentem i zarządcą określonych zasobów rzeczowych i finansowych. Dlatego, rozpatrując role szkół wyższych w rozwoju społeczno-gospodarczym regionów, na przykład nie można zapominać o wkładzie tego sektora w rozwój infrastrukturalny. Uczelnie sa przecież właścicielami: gruntów, budynków, wyposażenia. Atrakcyjne budynki uczelni często stanowią o prestiżu zarówno jej, jak i miejscowości, w której są zlokalizowane².

Zasygnalizowana powyżej mnogość funkcji, jakie pełnią szkoły wyższe, powoduje, że problem wzajemnych relacji pomiędzy szkołą a podmiotami z otoczenia regionalnego obecnie nabiera niezwykłego znaczenia.

W niniejszym artykule podjęto problem koncepcji tzw. trzeciej misji, a więc różnorodnych działań szkół wyższych dedykowanych społecznościom lokalnym. Zasadniczym celem artykułu jest próba włączenia się w dyskusję dotycząca zakresu pojęciowego tego terminu dzięki krytycznej analizie literatury krajowej i zagranicznej oraz prezentacji wyników badań własnych. Celem towarzyszącym jest także chęć udzielenia odpowiedzi na pytanie o znaczenie trzeciej misji w strategiach zarządczych szkół wyższych w Polsce w odniesieniu do tradycyjnie wyodrębnionych misji akademickich - kształcenia oraz prowadzenia badań naukowych.

\section{Koncepcja trzeciej misji}

Znaczenie współpracy uczelni z otoczeniem odzwierciedla, coraz częściej obecny w literaturze przedmiotu, poglad tzw. trzeciej misji uczelni (obok kształcenia oraz prowadzenia badań naukowych uważanych za tzw. pierwszą i drugą misję). Należy podkreślić, że w momencie powstania szkół wyższych trzecia misja nie była rdzeniem misji akademickiej, tak jak dwa podstawowe strumienie aktywności - kształcenie i prowadzenie badań. Jednak aktualnie uważa się, że koncepcja ta wyróżnia się i jest ważna sama w sobie, stąd zasługuje na szczególne warunki i środki zapewniające jej sprawną realizację [Molas-Gallart, Salter, Patel, Scott, Duran, 2002, s. 4], co uzasadnia podejmowanie tego zagadnienia w pracach naukowych.

${ }^{2}$ Więcej na ten temat w: [Piotrowska-Piątek, 2014, s. 37-51]. 
W ciagu ostatnich kilku lat przedsiębiorczość akademicka i różne formy aktywności szkół wyższych w zakresie trzeciej misji zajmują ważne miejsce w politykach publicznych w obszarze systemu szkolnictwa wyższego zarówno na szczeblu krajowym, jak i Unii Europejskiej [Kwiek, 2012, s. 34]. Nie ulega wattpliwości, że główny nurt zmian w europejskim systemie szkolnictwa wyższego - proces boloński - z uwagi na przesłanki dla troski o społeczeństwo i rynek pracy, przyczynia się do wzmocnienia komunikacji uczelni z interesariuszami. Oceniając okres przed rozpoczęciem reform bolońskich, trzeba przyznać, że w pewnych obszarach kształcenia (inżynieria, medycyna, ekonomia, zarządzanie, prawo) dialog z interesariuszami był dobrze rozwinięty. Jednak proces boloński rozszerzył zakres i podniósł rangę tego dialogu. Wpływ interesariuszy został również wzmocniony przez wprowadzenie nowych struktur zarządczych, takich jak rady interesariuszy, które funkcjonuja jako ciała doradcze w szkołach wyższych w wielu europejskich krajach. Warto także podkreślić, że bezpośredni wpływ interesariuszy nadal wywołuje sceptycyzm w tradycyjnych instytucjach, a mimo to idea konsultowania się $z$ zewnętrznymi partnerami $w$ związku $z$ reorientacja programów studiów jest już teraz szeroko akceptowana we wszystkich typach szkó [Reichert, 2010, s. 117].

Analiza krajowej i zagranicznej literatury przedmiotu wskazuje, że poszczególni autorzy terminem trzecia misja określaja podejmowane przez szkoły wyższe aktywności pochodne kształceniu i badaniom naukowym, skierowane w stronę: społeczności lokalnych, regionalnych lub ogółu społeczeństwa. Nie ma natomiast zgodności co do zakresu i form realizacji tych aktywności. Wspomniani autorzy akcentują nieco inne aspekty tego pojęcia. Celem zobrazowania tego wniosku, poniżej zaprezentowano wybrane przykłady zaczerpnięte z literatury przedmiotu, które uporządkowano od definicji zakresowo szerokich, które to podejście charakterystyczne jest dla większości badaczy zajmujących się tym problemem, do wąskich.

Leja terminem trzecia misja określa rozwój różnych form kształcenia przez całe życie, adresowanych do dzieci i młodzieży, osób chcących uzupełnić kwalifikacje lub rozwijać zainteresowania, jednocześnie tych, którzy zamierzaja zmienić zawód bądź są do tego zmuszeni, niezależnie od wieku i wykształcenia. Według cytowanego autora, trzecią misją jest zarazem rozwijanie współpracy z gospodarką w zakresie transferu i komercjalizacji technologii oraz odgrywanie roli kulturotwórczej przez uczelnię [Leja, 2013, s. 159-160].

Równie szeroko trzecią misję definiują autorzy Diagnozy stanu sækolnictwa my šszego $w$ Polsce. Określając ją ogólnie jako relacje uczelni z sektorem przedsiębiorstw, z sektorem publicznym oraz z sektorem pozarządowym, w jej ramach wyróżniają następujące działania:

- komercjalizacja wyników badań naukowych;

- uczestnictwo w inicjatywach regionalnych mających na celu podniesienie konkurencyjności gospodarczej i atrakcyjności regionów;

- $\quad$ współpraca uczelni z pracodawcami w celu dostosowania programów kształcenia do wymagań rynku pracy;

- udział praktyków spoza uczelni w procesie kształcenia oraz badaniach naukowych [Ernst\&Young, s. 96]. 
Podobnie autorzy raportu pt.: Produktywność nankowa sұkół publicznych w Polsce określają trzecią misję jako współpracę uczelni z biznesem i środowiskiem zewnętrznym [Wolszczak-Derlacz, Parteka, Kuczyński, 2010, s. 16]. W szerokim kontekście definiują ją jako zbiór działań przyczyniających się do innowacji oraz społecznego i ekonomicznego rozwoju kraju lub regionu, w wąskim jako współpracę uczelni z otoczeniem zewnętrznym, a w szczególności przemysłem i władzami [Wolszczak-Derlacz, Parteka, Kuczyński, 2010, s. 76].

Z kolei, W. Banyś trzecią misję sprecyzował jako wzmacnianie współpracy między uczelniami a szeroko rozumianym otoczeniem społeczno-gospodarczym, w tym przedsiębiorcami, z transferem i komercjalizacja wiedzy czy z wprowadzaniem mechanizmów finansowych i fiskalnych, wspierających innowacyjność przedsiębiorstw [Strategia, żmiany, ro:zójj, 2013, s. 23]. Warto zauważyć, że w tym podejściu do pojęcia trzeciej misji są włączane działania będące w gestii polityk publicznych, na które obecnie uczelnie nie mają bezpośredniego wpływu.

Gregor i Kozakiewicz za trzecią misję uczelni uważają taki kierunek działań uczelni, który zmierza do pełnego „otwarcia się” uczelni na otoczenie bądź do nawiazzywania kontaktów z szeroko pojętym biznesem, zarówno w sferze edukacji, jak i badań naukowych. Opierając się na przykładzie Uniwersytetu Łódzkiego, do działań z zakresu trzeciej misji zaliczają oni: uwzględnianie w ofercie edukacyjnej (programach kształcenia) potrzeb rynku pracy, uruchomienie biura karier, organizowanie targów pracy, nawiazywanie współpracy międzyuczelnianej w wymiarze globalnym w ramach studiów i kursów, programy stażu i praktyk zawodowych, powołanie Rady Biznesu, ofertę studiów podyplomowych, zatrudnianie praktyków, funkcjonowanie uczelnianych jednostek z zakresu akceleracji i transferu technologii, organizowanie cyklicznej konferencji z zakresu transferu wiedzy i komercjalizacji technologii [Gregor, Kozakiewicz, 2012, s. 95-101].

W literaturze anglojęzycznej trzecią misję bardzo często określa się jako tzw. trzeci strumień, podkreślając znaczenie przychodów uzyskiwanych poza systemem wsparcia publicznego oraz opłat ponoszonych przez studentów. Na przykład trzęi strumień według M. Sancheza-Barrioulengo (zwany także przez wspomnianego autora społecznym zaangażowaniem) to: powstawanie, wykorzystywanie, zastosowanie, eksploatacja wiedzy i innych zdolności uniwersytetu poza środowiskiem akademickim [Sanchez-Barrioluengo, 2014].

Jednocześnie można spotkać podejścia bardzo wąskie, utożsamiające trzecią misję wyłącznie z komercjalizacją badań naukowych [George, Jain, Maltarich, 2005]. Takie podejście jest bliskie badaczom związanym $\mathrm{z}$ akademickimi inkubatorami przedsiębiorczości oraz centrami transferu technologii. Wydaje się, że można określić je jako technokratyczne ujęcie trzeciej misji.

Dyskontując przesłania powyżej przytoczonych ujęć definicyjnych rozważanego pojęcia, dotychczasowe badania własne oraz doświadczenia praktyczne wynikające z pełnienia w przeszłości funkcji kierownika podstawowej jednostki organizacyjnej szkoły wyższej, autorka proponuje, aby przez pojęcie trzeciej misji rozumieć wszystkie aktywności szkół wyższych dedykowane społecznościom lokalnym i regionalnym w obszarach: kształcenia prowadzenia i udostępniania rezultatów badań naukowych oraz wynikające z posiadania przez uczelnie określonych zasobów finansowych i rzeczowych. 
Taką również perspektywę terminologiczną autorka przyjęła w trakcie badań empirycznych, których wyniki zaprezentowano poniżej.

\section{Metodyka i organizacja badań własnych}

W celu zbadania, w jaki sposób szkoły wyższe (a przede wszystkim osoby nimi zarządzające) percypuja trzecia misję oraz jej znaczenie w swoich misjach i strategiach, przeprowadzono badanie empiryczne ${ }^{3}$, którym objęto wszystkie szkoły wyższe działajace pod nadzorem Ministra Nauki i Szkolnictwa Wyższego (N-377). W założeniu miało to być badanie pełne. Operat do badań stanowił wykaz uczelni publicznych i niepublicznych o statusie uczelni działającej, który ustalono na podstawie4:

- $\quad$ rejestru uczelni niepublicznych i związków uczelni niepublicznych dostępnego w systemie POL-on (N-282);

- $\quad$ wykazu publicznych uczelni akademickich (N-59);

- $\quad$ wykazu państwowych wyższych szkół zawodowych (N-36).

Badanie przeprowadzono $\mathrm{w}$ formie indywidualnej ankiety pocztowej skierowanej do rektorów uczelni w okresie od stycznia do lutego 2015 roku. W celu osiagnięcia optymalnej kompletności badania w trakcie procesu zbierania materiału badawczego również prowadzono monit telefoniczny oraz korzystano z poczty elektronicznej. Ostateczny zwrot ankiet w odniesieniu do poszczególnych typów szkół przedstawiał się następująco:

- $\quad$ w grupie publicznych uczelni akademickich uzyskano 31 poprawnie wypełnionych ankiet, co objęło 52,5\% zbiorowości w tej grupie szkół;

- $\quad$ w grupie państwowych wyższych szkół zawodowych uzyskano 18 poprawnie wypełnionych ankiet, co objęło 50\% zbiorowości w tej grupie szkół;

- w grupie uczelni niepublicznych uzyskano 51 poprawnie wypełnionych ankiet, co objęło 18,1\% zbiorowości w tej grupie szkól.

Jak więc widać, w efekcie nie były to badania pełne (pomimo pierwotnego zamiaru). Jednak z uwagi na to, że co druga publiczna uczelnia akademicka, co druga państwowa wyższa szkoła zawodowa oraz prawie co piąta uczelnia niepubliczna wzięły udział w badaniu, to należy założyć, że stanowią one dobrą reprezentację zbiorowości. Nie ma bowiem metody na ustalenie post factum losowości próby. Podobnie sam przedmiot badań jest na tyle mało rozpoznany, że nie ma w zasadzie możliwości bezpośredniego odniesienia własnych wyników do badań innych autorów.

W niniejszym opracowaniu zaprezentowano odpowiedzi na następujące pytania badawcze:

\footnotetext{
${ }^{3}$ Badanie miało szerszy charakter w stosunku do kwestii prezentowanych w niniejszym artykule.

${ }^{4}$ Dodatkowo, operat ustalony na podstawie podanych rejestrów skonfrontowano z informacjami podanymi na stronach internetowych szkół wyższych. W grupie uczelni niepublicznych kilkanaście szkół widniejących w Rejestrze uczelni niepublicznych $i$ zpiazkón uczelni niepublicznych nie prowadziło działalności i było w tracie likwidacji.
} 
- $\quad$ w jaki sposób osoby zarządzające szkołami wyższymi percypuja pojęcie trzeciej misji?

- $\quad$ jakie znaczenie osoby zarządzające szkołami wyższymi przypisują trzeciej misji względem podstawowych misji akademickich w realizowanej strategii uczelni?

Wyniki badania zaprezentowano w podziale na typy szkół, takie jak: publiczne uczelnie akademickie, państwowe wyższe szkoły zawodowe, uczelnie niepubliczne.

\section{Trzecia misja uczelni w opinii rektorów szkół wyższych - prezentacja wyników badania}

W celu rozpoznania, w jaki sposób respondenci (rektorzy szkół wyższych) percypuja pojęcie trzeciej misji, poproszono ich o zapoznanie się z propozycją definicji, która przedstawiono w Stownicžku pojeć w Instrukcji wypetniania kwestionariusza ankiety ${ }^{5}$. Respondentów poproszono o określenie, czy zgadzają się z takim postrzeganiem trzeciej misji uczelni i o krótką wypowiedź na ten temat (na podstawie swoich doświadczeń oraz realizowanej misji i strategii uczelni). Rozkłady odpowiedzi na to pytanie prezentuje wykres 1. Jak widać, respondenci prawie jednomyślnie zgadzali się z zaproponowaną definicja trzeciej misji, przy czym średnio co drugi respondent sformułował również własną wypowiedź (którą umownie nazwano definicją rozszerzająca).

Definicje rozszerzające zaproponowane przez respondentów poddano analizie jakościowej z uwagi na kryteria sformułowane w postaci poniższych pytań badawczych.

1. W jaki sposób uczelnia określa adresata swoich działań w zakresie trzeciej misji?

2. Jakie działania uczelnia podejmuje w ramach trzeciej misji?

3. Co stanowi istotę trzeciej misji?

4. Dlaczego szkoły wyższe powinny prowadzić takie działania?

Formułując powyższe pytania (które pełniły funkcję kryteriów analizy), odwołano się do uniwersalnego rozumienia misji organizacji jako stwierdzenia definiującego przede wszystkich dla kogo i w jakim celu funkcjonuje organizacja. Następnie dokonano syntetyzacji oraz redukcji uzyskanego materiału badawczego, a wyniki zaprezentowano w tabeli 1.

\footnotetext{
${ }^{5}$ Definicja ta została zaprezentowana we wcześniejszej części artykułu.
} 
WYKRES 1.

Struktura odpowiedzi na pytanie: W instrukcji wypełniania kwestionariusza ankiety przedstawiłam propozycję definicji tzw. trzeciej misji uczelni. Czy Pani/Pan zgadza się z takim postrzeganiem trzeciej misji uczelni?

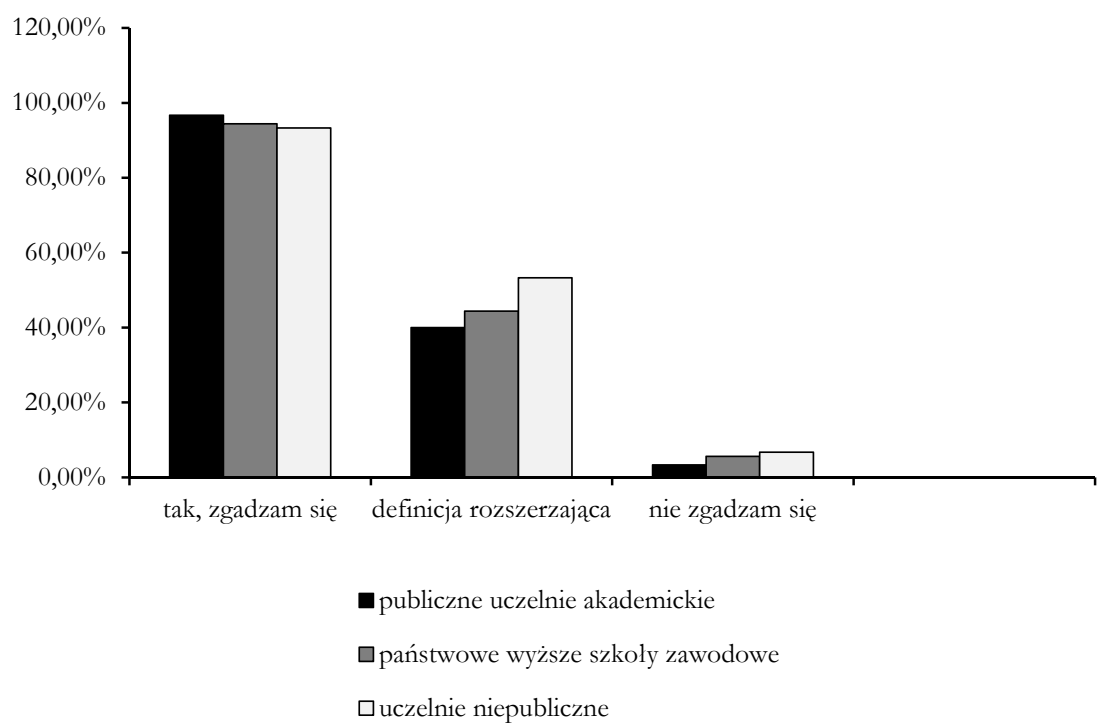

Źródło: opracowanie własne na podstawie wyników badania.

Jak można zauważyć, trzecia misja w opinii rektorów jest działalnością skierowanac w stronę interesariuszy z otoczenia lokalnego obejmującą różnorodne aktywności - związane z: kształceniem, prowadzeniem badań naukowych, szeroko pojętą współpraca z otoczeniem. Warto również zauważyć pewną sprzeczność. Rektorzy, określając istotę trzeciej misji w kategoriach: służebności, zaangażowania, promieniowania na region, jednocześnie wśród przyczyn takich działań wskazują: budowanie marki, oddziaływanie na rynki docelowe, można by powiedzieć pobudki ekonomiczne. Jednak ta sprzeczność ma, w opinii autorki, charakter pozorny. Należy przypomnieć bowiem, że szkoła wyższa to obecnie nie tylko idea sacrum wiedzy, ale także organizacja, dla której wzorcem powoli staje się nowoczesne zarządzanie w warunkach społecznej gospodarki rynkowej. 
TABELA 1.

\section{Pojęcie trzeciej misji uczelni w opinii rektorów szkół wyższych - wyniki analizy jakościowej w podziale na typy uczelni}

\begin{tabular}{|c|c|c|c|}
\hline \multirow{2}{*}{\begin{tabular}{|c|} 
Pytania badaw- \\
cze/kryteria anali- \\
zy \\
\end{tabular}} & \multicolumn{3}{|c|}{ Typ uczelni } \\
\hline & $\begin{array}{l}\text { Publiczne uczelnie akade- } \\
\text { mickie }\end{array}$ & \begin{tabular}{|c|} 
Państwowe wyższe \\
szkoły zawodowe
\end{tabular} & Uczelnie niepubliczne \\
\hline $\begin{array}{l}\text { W jaki sposób uczelnia } \\
\text { określa adresata swo- } \\
\text { ich działań w zakresie } \\
\text { trzeciej misji? }\end{array}$ & $\begin{array}{l}\text { - społeczność lokalna } \\
\text { - społeczność regionalna } \\
\text { - } \text { szersze grono odbiorców }\end{array}$ & 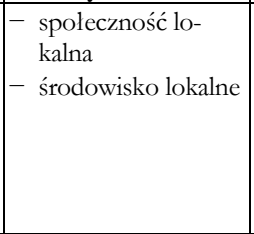 & $\begin{array}{l}\text { - } \text { społeczność lokalna } \\
\text { - społeczność regionalna } \\
\text { - potencjalni interesariusze spo- } \\
\text { łeczni } \\
\text { - środowisko w miejscu działalnoś- } \\
\text { ci uczelni } \\
\text { - } \text { miasto, region, kraj }\end{array}$ \\
\hline $\begin{array}{l}\text { Jakie działania uczel- } \\
\text { nia podejmuje w ra- } \\
\text { mach trzeciej misji? }\end{array}$ & \begin{tabular}{|l|} 
- kulturotwórcze \\
- artystyczne \\
- aktywizujące społecznie \\
- na zasadzie wolontariatu \\
- takie, które wpływają na \\
rozwój młodzieży (akade- \\
mickiej) \\
- upowszechnianie nauki po- \\
przez centrum transferu \\
technologii oraz akademicki \\
inkubator przedsiębiorczości \\
- współpraca z biznesem \\
- szkolenia wynikające z po- \\
siadanej infrastruktury
\end{tabular} & \begin{tabular}{|l|} 
- \\
działalność kul- \\
- działalność in- \\
nowacyjna \\
- organizowanie kon- \\
ferencji \\
- wykorzystanie in- \\
frastruktury uczelni \\
na rzecz rozwoju \\
miasta \\
- upowszechnienie \\
i popularyzowanie \\
badań naukowych
\end{tabular} & 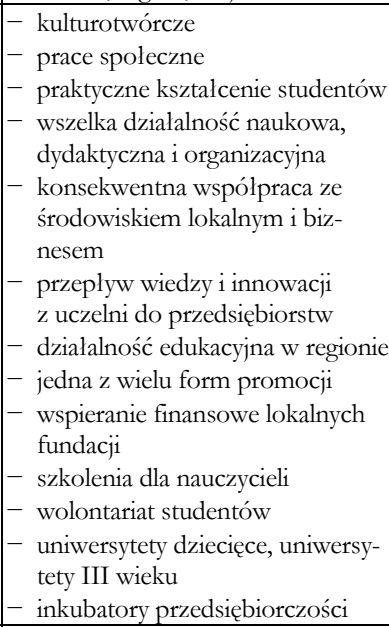 \\
\hline $\begin{array}{l}\text { Co stanowi istotę } \\
\text { trzeciej misji? }\end{array}$ & $\begin{array}{l}\text { - } \text { służebność uczelni wobec } \\
\text { regionu } \\
\text { - zaangażowanie uczelni we } \\
\text { współpracę z otoczeniem } \\
\text { społeczno-gospodarczym } \\
\text { - zaangażowanie instytucji } \\
\text { akademickich w procesy } \\
\text { rozwoju społeczno- } \\
\text { gospodarczego } \\
\text { - odpowiedź uczelni na ocze- } \\
\text { kiwania otoczenia } \\
\text { - zdolność uczelni do ko- } \\
\text { mercjalizacji osiagnięć nau- } \\
\text { kowych }\end{array}$ & \begin{tabular}{|l} 
- wspieranie rozwoju \\
społeczności lokal- \\
nych \\
- współpraca z oto- \\
czeniem spo- \\
łeczno- \\
gospodarczym \\
- integracja uczelni \\
ze środowiskiem \\
lokalnym
\end{tabular} & $\begin{array}{l}- \text { oddziaływanie na społeczności } \\
\text { lokalne } \\
- \text { obywatelskie i społeczne zaanga- } \\
\text { żowanie uczelni }\end{array}$ \\
\hline $\begin{array}{l}\text { Jakie są przyczyny } \\
\text { podejmowania takich } \\
\text { działań? }\end{array}$ & \begin{tabular}{|l} 
- \\
społeczność lokalna jest \\
rynkiem docelowym uczelni \\
- bez takich działań uczelnia \\
nie osiagnie dobrych rezulta- \\
tów rekrutacyjnych
\end{tabular} & $\begin{array}{l}- \text { warunkuje po- } \\
\text { strzeganie uczelni } \\
\text { w środowisku lo- } \\
\text { kalnym } \\
\text { - } \text { ma znaczenie pro- } \\
\text { mocyjne }\end{array}$ & $\begin{array}{l}\text { - buduje markę uczelni, promuje } \\
\text { - sugestie ministerstwa } \\
\text { - postulaty procesu bolońskiego } \\
\text { - warunek rozwoju uczelni }\end{array}$ \\
\hline
\end{tabular}

Źródło: opracowanie własne na podstawie wyników badania. 
W celu rozpoznania znaczenia, jakie przypisują rektorzy działaniom z zakresu trzeciej misji, poproszono ich w kwestionariuszu ankiety, aby biorąc pod uwagę realizowana przez uczelnię misję i strategię, podzielili 10 punktów ${ }^{6}$ między trzy obszary: kształcenie, prowadzenie badań naukowych oraz trzecią misję (przy założeniu, że im więcej przyznanych punktów, tym większa waga danego obszaru w realizowanej misji i strategii uczelni). Do analizy rozkładów wyborów respondentów wykorzystano średnią arytmetyczna, a wyniki zaprezentowano na wykresie 2. Jak widać, stosunkowo największe znaczenie w realizowanej strategii uczelni przypisują trzeciej misji rektorzy państwowych wyższych szkół zawodowych (średnio 2,44 pkt wobec 2,15 w przypadku publicznych uczelni akademickich i odpowiednio 2,13 w przypadku uczelni niepublicznych). Wynik taki wskazuje wyraźna, regionalną orientację państwowych wyższych szkół zawodowych, w porównaniu z innymi typami szkół, co potwierdzają również wcześniejsze badania autorki [Piotrowska-Piątek, 2014]. Ponadto, wyniki dowodzą, że w opinii osób zarządzających szkołami wyższymi, działania z zakresu trzeciej misji są wyraźnie wyodrębnione w misjach i strategiach uczelni w stosunku do podstawowych, tradycyjnie postrzeganych misji akademickich - kształcenia i prowadzenia badań naukowych.

WYKRES 2.

\section{Znaczenie trzeciej misji w misji i strategii uczelni, w opinii rektorów szkół wyższych, w podziale na typy uczelni ${ }^{7}$}

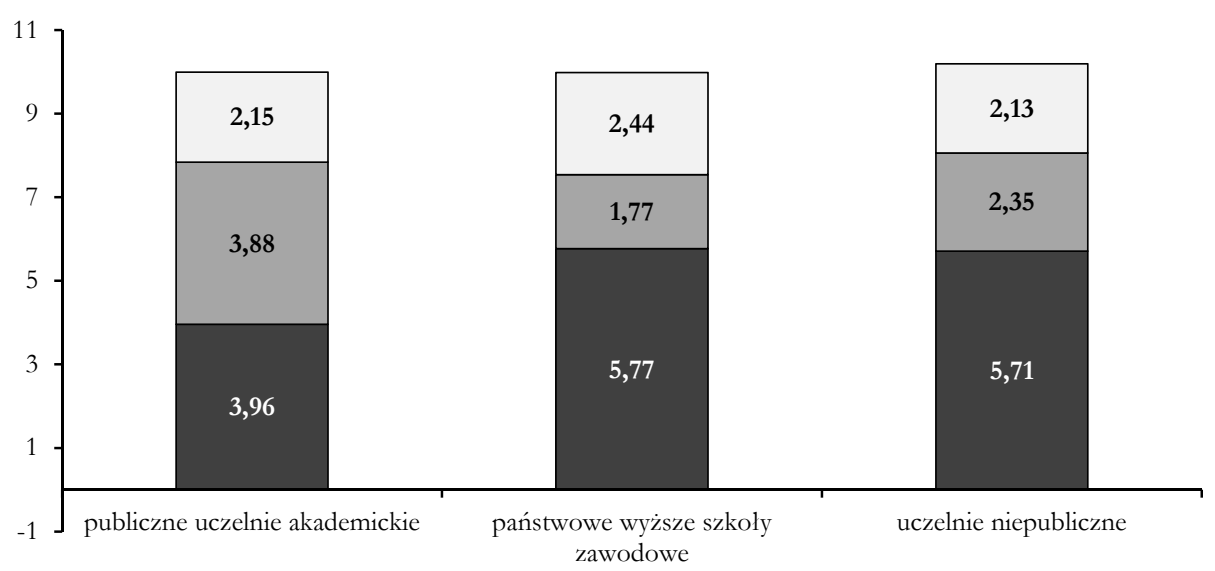

口obszar kształcenia $\quad \square$ obszar prowadzenia badań naukowych $\quad \square$ trzecia misja

Źródło: opracowanie własne na podstawie wyników badania.

\footnotetext{
${ }^{6}$ Konstrukcję tego pytania oparto na skali sumowania ocen.

7 Sumy nie wynoszą dokładnie $10 \mathrm{z}$ uwagi na prezentowanie wartości do 2. miejsca po przecinku oraz przypadki przekraczania podanej skali przez respondentów.
} 


\section{Podsumowanie}

W obecnie toczącej się dyskusji, dotyczącej roli edukacji wyższej w procesach rozwoju społeczno-gospodarczego na różnych poziomach delimitacji przestrzennej, szkoły wyższe są przedstawiane $\mathrm{w}$ roli inicjatora zmian, podejmującego wyzwania wynikające nie tylko z globalizacji, ale przede wszystkim potrzeb wspólnot regionalnych i lokalnych. Zadaniem szkoły wyższej jest przyczynianie się do zrównoważonego rozwoju wspólnot regionalnych przez odpowiednie kształtowanie oferty edukacyjnej i programów nauczania, a tym samym zwiększanie możliwości zatrudniania absolwentów. W aktualnych warunkach gospodarowania, które często nazywa się ekonomią typu based-knowledge, istotna rolą szkół wyższych jest przyczynianie się do rozwoju regionu, w którym funkcjonują również w ramach działalności badawczej i eksperckiej oraz włączanie się w sieci wspólpracy regionalnej.

Jednym z głównych celów współczesnych uczelni jest zatem współpraca z otoczeniem. Uczelnie aktywnie angażujące się we współpracę z otoczeniem oraz upowszechnianie i komercjalizację wyników badań naukowych często są określane mianem uniwersytetów trzeciej generacji [Kardas, 2013, s. 81], uniwersytetów przedsiębiorczych [Clark, 1998, s. 6], hybrydowych.

W niniejszym artykule podjęto problem niejednoznaczności terminologicznej pojęcia trzeciej misji uczelni i jej znaczenia w praktyce zarządzania szkołą wyższa. W celu sformułowania problemów badawczych autorka zastosowała analizę literatury przedmiotu oraz prezentację wyników badań własnych. Stwierdzono, że typowe jest szerokie ujęcie badanego zagadnienia, skutkujące niejednolitym stanowiskiem poszczególnych badaczy co do zakresu i form realizacji aktywności uczelni w obszarze trzeciej misji. Dyskontując prezentowane w literaturze przedmiotu ujęcia definicyjne oraz wyniki badań własnych, autorka proponuje, aby pojęciem trzeciej misji uczelni określać wszystkie aktywności szkół wyższych dedykowane społecznościom lokalnym i regionalnym w obszarach: kształcenia, prowadzenia i udostępniania rezultatów badań naukowych, jak również wynikające z posiadania przez uczelnie określonych zasobów finansowych i rzeczowych. Zaprezentowane wyniki badań świadczą także o tym, że aktywności w obszarze trzeciej misji stanowią istotny element $\mathrm{w}$ procesie formułowania koncepcji zarządczych na poziomie misji i strategii rozwoju uczelni.

\section{Literatura}

Clark B. R. 1998 Creating Entrepreneurial Universities: Organizational Pathways of Transformation, Pergamon Press, New York.

Ernst\&Young Business Advisory, Instytut Badań nad Gospodarką Rynkową, 2009, Diagnoza stanu szkolnictwa wy ższego w Polsce, dokument elektroniczny, tryb dostępu: [http://www.nauka.gov.pl/g2/oryginal/2013_05/fa5b19e372e1bed45db817b83 80c8468.pdf, data wejścia: 20.06.2015]. 
George G., Jain S., Maltarich M. A. 2005 Academics or Entrepreneurs? Entrepreneurial Identity and Invention Disclosure Behavior of University Scientists, September 6, dokument elektroniczny, tryb dostępu: [http://ssrn.com/abstract=799277, data wejścia: 25.06.2015].

Gregor B., Kozakiewicz M. 2012 Uniwersytet Łódzki dla pracodawców - doświadczenia uczelni we wdrażaniu trzeciej misji w sferze edukacji ekonomicznej, [w:] Edukacja ekonomiczna wobec przemian otoczenia społeczno-gospodarczego, J. Dietl, Z. Sapijaszka (red.), Wydawnictwo Fundacji Edukacyjnej Przedsiębiorczości, Łódź.

Kardas M. 2013 Rola uczelnianych centrów transferu technologii w procesie komercjalizacji wyników badań naukowych i prac rozwojowych, [w:] Uniwersytet trzeciej generacji. Stan i perspektyny rožpoju, Burawski D. (red.), Europejskie Centrum Wspierania Przedsiębiorczości, Poznań.

Kwiek M. 2012 The Growing Complexity of the Academic Enterprise in Europe: A Panoramic View, [in:] The Modernisation of European Universities. Cross-National Academic Perspectives, Kwiek M., Kurkiewicz A., Peter Lang (eds.), Frankfurt am Main.

Leja K. 2013 Zarzqadzanie uczelniq. Koncepcje i wspótczesne wyzwania, WoltersKluwer, Warszawa.

Molas-Gallart J., Salter A., Patel P., Scott A., Duran X. 2002 Measuring Third Stream Activities. Final Report to the Russell Group of Universities, SPRU, University of Sussex, Brighton.

Piotrowska-Piątek A. 2014 Szkoly wyższe jako çynnik rozwoju regionalnego, „Biuletyn Rozwój Regionalny i Polityka Regionalna", nr 28.

Piotrowska-Piątek A. 2014 Driatania na rzecz rozwoju regionu w dokumentach strategicznych uczelni w Polsce w swietle analizy treśsi. Komunikat z badań, „Optimum. Studia Ekonomiczne", nr 3.

Reichert S. 2010 The intendent and unintendent effects of the Bologna process, „Higher Education Management and Policy", vol. 22/1.

Sanchez-Barrioluengo M. 2014 Articulating the "three missions” in Spanish universities, „Research Policy”, vol. 43.

Strategia, zmiany, rozwój, rozmowa z prof. Wiesławem Banysiem, „Forum Akademickie", marzec 2013.

Wolszczak-Derlacz J., Parteka A., Kuczyński J. 2010 Produktywność naukowa wyżşych szkót publicznych w Polsce: Bibliometryczna analiza porównawcza, Raport w ramach projektu „Sprawne Państwo”, Ernst \& Young, Warszawa. 